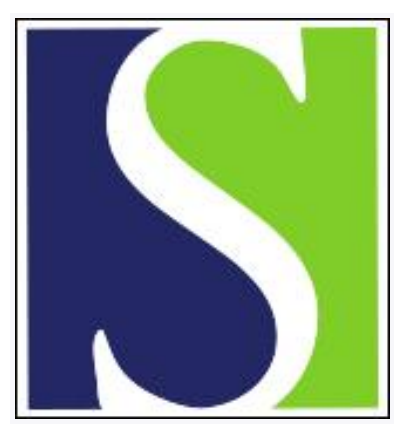

Scand J Work Environ Health 2008;34(3):230-233

https://doi.org/10.5271/sjweh.1242

Issue date: 30 Jun 2008

Follow-up study of cancer incidence after chlorophenol exposure in a community in southern Finland

by Lampi P, Tuomisto J, Hakulinen T, Pukkala E

Affiliation: Päijät-Häme Social and Health Group, Keskussairaalankatu 7, FI-15850 Lahti, Finland. pentti.lampi@phsotey.fi

Key terms: cancer incidence; cancer registration; cancer risk; chlorophenol exposure; chlorophenols; Finland; follow-up study; ground water; population exposure; promotion effect

This article in PubMed: www.ncbi.nlm.nih.gov/pubmed/18728913

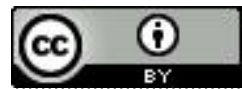




\title{
Follow-up study of cancer incidence after chlorophenol exposure in a community in southern Finland
}

\author{
by Pentti Lampi, MD, ${ }^{1}$ Jouko Tuomisto, MD, ${ }^{2}$ Timo Hakulinen, ScD, ${ }^{3}$ Eero Pukkala, PhD ${ }^{3,4}$
}

\begin{abstract}
Lampi P, Tuomisto J, Hakulinen T, Pukkala E. Follow-up study of cancer incidence after chlorophenol exposure in a community in southern Finland. Scand J Work Environ Health 2008; 34(3):230-233.
\end{abstract}

\begin{abstract}
Objectives In the 1970s and 1980s, people in a village in southern Finland had been exposed to high concentrations of chlorophenols in the drinking water and in fish from a nearby lake. An ecological analysis and a case-control study conducted around 1990 indicated significant excess in the incidence of non-Hodgkin's lymphoma and soft-tissue cancer in the municipality and a relationship between the chlorophenol exposure and the incidence of these cancers. The present article reports a follow-up of cancer risk in the same study area during a 20-year period after the closing of the old water intake plant, which was contaminated by chlorophenols.

Methods The observed and expected numbers of cancer were obtained for three periods, 1953-1971 (before exposure), 1972-1986 (during exposure) and 1987-2006 (after exposure), for all cancers combined and separately for cancers potentially related to chlorophenols.

Results The present study demonstrates that all of the cancer risks returned to the average population level during the 20-year period after the old water intake plant was closed and chlorophenol exposure stopped.

Conclusions The rapid changes in cancer risk after changes in chlorophenol exposure suggest that chlorophenols may have a promotion effect in the carcinogenic process.
\end{abstract}

Key terms cancer registration; cancer risk; chlorophenols; ground water; population exposure; promotion effect.

At the end of 1987, high concentrations (70-140 $\mu \mathrm{g} / \mathrm{l})$ of chlorophenols were accidentally found in ground water in Järvelä, an industrial village with 2000 inhabitants located in the southern Finland municipality of Kärkölä (5300 inhabitants). Most of the people in Kärkölä got their daily drinking water from this ground water. Chlorophenol levels between 56000 and $190000 \mu \mathrm{g} / \mathrm{l}$ were found deep in the ground water between the main employer in Järvelä, a sawmill using chlorophenols, and the water intake plant of the village. The sawmill produced plywood, chipboard, and lumber.

From the 1940 until 1984, a fungicide "KY-5" had been used to inhibit the growth of bluestain fungus in timber. The main active component of the fungicide is 2,3,4,6-tetrachlorophenol, with minor components of pentachlorophenol and 2,4,6-trichlorophenol. Impurities such as polychlorodibenzo-p-dioxins (PCDD) and polychlorodibenzofurans (PCDF) have been also found in technical and commercial products. Lake Valkjärvi, downstream from the village, was also found to be contaminated with chlorophenols, and the concentrations were 2.6 to $11.0 \mu \mathrm{g} / \mathrm{l}$. Fish from the lake contained chlorophenols from $175 \mu \mathrm{g} / \mathrm{kg}$ (perch) to $925 \mu \mathrm{g} / \mathrm{kg}$ (zander) per wet weight (1).

The community was exposed to chlorophenols (2,3,4,6-tetrachlorophenol, 2,4,6-trichlorophenol, and pentachlorophenol) probably-according to sediment analyses (2,3) - for at least 15 years via drinking water from the waterworks and fish from Lake Valkjärvi (1, $2)$. There was no exposure to $\operatorname{PCDD}$ or $\operatorname{PCDF}(1,3,4)$. People exposed to the ground water with chlorophenols had symptoms similar to those observed among persons with occupational chlorophenol exposure (5).

A two-part investigation of cancer risk in Kärkölä was conducted immediately after the population exposure with chlorophenols was confirmed (6). An ecological analysis at the municipality level revealed that the incidence of soft-tissue cancer and non-Hodgkin's

1 Päijät-Häme Social and Health Group, Lahti, Finland.

2 National Public Health Institute, Department of Environmental Health, Kuopio, Finland.

3 Finnish Cancer Registry, Institute for Statistical and Epidemiological Cancer Research, Helsinki, Finland.

4 School of Public Health, University of Tampere, Tampere, Finland.

Reprint requests to: Pentti Lampi, Päijät-Häme Social and Health Group, Keskussairaalankatu 7, FI-15850 Lahti, Finland. [E-mail: pentti.lampi@phsotey.fi] 
lymphoma in the municipality of Kärkölä was significantly higher than in the rest of the cancer-control region. A subsequent case-control analysis showed a significantly elevated risk of non-Hodgkin's lymphoma among persons who consumed fish from the contaminated lake or who were exposed to chlorophenol-contaminated drinking water [combined risk ratio (odds ratio) for these factors 6.9, 95\% confidence interval $(95 \% \mathrm{CI})$ 1.1-74 (6)]. These exposures may also have played a role in the development of soft-tissue cancers.

In the 1970s, several case-control studies reported an association between chlorophenols and non-Hodgkin's lymphoma and soft-tissue sarcoma, but, later, the risk was usually attributed to their minor impurities, PCDD and PCDF ("dioxins") (7). Recently, an association between occupational chlorophenol exposure with softtissue sarcoma was reported from a large study in the United States (8), but no strong evidence was found for an association with non-Hodgkin's lymphoma (9).

Demers et al (10) studied the carcinogenicity of pentachlorophenol and tetrachlorophenol in a cohort of sawmill workers. The exposure was mainly (95\%) interpreted to be dermal. It is noteworthy that dioxins do not penetrate skin easily (11). There was an exposure-response relationship for non-Hodgkin's lymphoma, multiple myeloma, and kidney cancer (10). There was a decreased risk of soft-tissue sarcoma, but the number of cases was low. The effect was interpreted to be due to chlorophenols themselves, not to dioxin impurities. Richardson et al (12) performed a populationbased case-control study on non-Hodgkin's lymphoma. Among several of the chemicals assessed by exposure scores based on occupational history, chlorophenols were associated with non-Hodgkin's lymphoma.

As yet, the only study measuring dioxins in a population-based prospective case-control study individually is that of Tuomisto et al (7), which was based on 110 cases of soft-tissue sarcoma and 227 controls. In that study, the highest risk was found in the quintile with the lowest dioxin levels. Thus some evidence is accumulating that chlorophenol-related cancer risk may be due to the main chemical and not to the dioxin impurities.

In this article, we report a follow-up of cancer risk in the same study area during a 20 -year period after the closing of the old water intake plant with chlorophenol contamination. Since then, tap water has been taken from a separate ground-water area, and people have not been exposed to chlorophenols via drinking water. There was also a recommendation given by the local health authorities that fish from the polluted lake should not be eaten. According to some animal studies with pentachlorophenol $(13,14)$, chlorophenols have a promoter effect in cancer development. Our hypothesis was that the excess risk should disappear soon after the exposure ended.

\section{Materials and methods}

The observed and expected numbers of cancer in the Kärkölä municipality were obtained for three periods, 1953-1971 (before exposure), 1972-1986 (during exposure) and 1987-2006 (after exposure), from files of the Finnish Cancer Registry for all cancers combined and separately for colon cancer [International Classification of Diseases, 10th revision (ICD-10) C18], bladder cancer [includes ureter and urethra (ICD-10 C66-C68)], soft-tissue cancer (ICD-10 C48-C49), Hodgkin's lymphoma (ICD-10 C81), non-Hodgkin's lymphoma (ICD10 C82-C85, C96), and leukemia (ICD-10 C91-C95). These are the same cancers that were included in the first study on the chlorophenol-exposure episode in Kärkölä (6). The expected numbers were based on the gender-, age-, and calendar-year-specific cancer incidence rates in the Tampere cancer control region (1.2 million inhabitants), to which the Kärkölä municipality belongs. Standardized incidence ratios (SIR) were calculated as ratios of the observed-to-expected numbers of cases, and exact $95 \%$ confidence intervals were defined under the Poisson assumption concerning the numbers of observed cases.

\section{Results}

The overall cancer incidence in the Kärkölä municipality was similar to that expected in each consecutive period. During 1972-1986, the incidences of soft-tissue cancer (SIR 3.19, 95\% CI 1.17-6.95) and non-Hodgkin's lymphoma (SIR 2.08, 95\% CI 1.14-3.49) were significantly increased (table 1). During 1953-1971, the incidence of colon cancer (SIR 1.90, 95\% CI 1.14-2.96) was increased significantly.

None of the site-specific SIR values were significantly increased during the last (after exposure) 20year period (table 1). The SIR values for the first and second 10 years of the period 1987-2006 did not differ significantly for any of the cancer sites. For nonHodgkin's lymphoma, the SIR value for 1987-1996 was 0.52 (95\% CI 0.14-1.32), and for 1997-2006 it was 1.02 (95\% CI 0.49-1.88). Both cases of soft-tissue cancer were diagnosed in 1997-2006 (SIR 1.27, 95\% CI 0.15-4.58).

\section{Discussion}

Both the observed and expected numbers of cancers were based on the files of the Finnish Cancer Registry. 
Table 1. Observed $(0)$ and expected $(E)$ numbers of cases cancer and the standardized incidence ratios (SIR = O/E) determined for Kärkölä in three calendar periods, both genders combined. $(95 \% \mathrm{Cl}=95 \%$ confidence interval).

\begin{tabular}{|c|c|c|c|c|c|c|c|c|c|c|c|c|}
\hline \multirow[t]{2}{*}{ Cancer } & \multicolumn{4}{|c|}{$1953-1971$} & \multicolumn{4}{|c|}{$1972-1986$} & \multicolumn{4}{|c|}{$1987-2006$} \\
\hline & 0 & $\mathrm{E}$ & SIR & $95 \% \mathrm{Cl}$ & 0 & $E$ & SIR & $95 \% \mathrm{Cl}$ & 0 & $E$ & SIR & $95 \% \mathrm{Cl}$ \\
\hline All sites & 284 & 278 & 1.02 & $0.91-1.14$ & 242 & 280 & 0.87 & $0.76-0.98^{\text {a }}$ & 401 & 473 & 0.85 & $0.77-0.93^{b}$ \\
\hline Colon cancer & 19 & 10.0 & 1.90 & $1.14-2.96^{\mathrm{a}}$ & 8 & 14.8 & 0.54 & $0.23-1.06$ & 20 & 28.3 & 0.71 & $0.43-1.09$ \\
\hline Bladder cancer & 3 & 5.2 & 0.57 & $0.12-1.67$ & 11 & 9.3 & 1.18 & $0.59-2.11$ & 8 & 16.2 & 0.49 & $0.21-0.97^{\mathrm{a}}$ \\
\hline Soft-tissue cancer & 0 & 1.8 & 0.00 & $0.00-2.02$ & 6 & 1.9 & 3.19 & $1.17-6.95^{\mathrm{a}}$ & 2 & 3.1 & 0.66 & $0.08-2.37$ \\
\hline Non-Hodgkin's lymphoma & 5 & 4.6 & 1.09 & $0.36-2.55$ & 14 & 6.7 & 2.08 & $1.14-3.49^{\mathrm{a}}$ & 14 & 17.5 & 0.80 & $0.44-1.34$ \\
\hline Hodgkin's lymphoma & 3 & 2.4 & 1.27 & $0.26-3.73$ & 1 & 2.4 & 0.42 & $0.01-2.33$ & 2 & 2.8 & 0.70 & $0.09-2.54$ \\
\hline Leukemia & 6 & 7.5 & 0.80 & $0.29-1.74$ & 10 & 8.3 & 1.20 & $0.58-2.21$ & 8 & 10.2 & 0.78 & $0.34-1.54$ \\
\hline
\end{tabular}

a $P<0.05$.

b $\mathrm{P}<0.001$.

The coverage of the national Finnish Cancer Registry is virtually complete (15), and there should be no variation in coverage over time or region. Although the diagnostic practices and even terminology used in cancer diagnostics has changed over the decades, these factors should not bias our relative risk estimates because the observed and expected numbers are based on exactly the same diagnostic and registration procedures and there is no difference in these aspects between Kärkölä and the reference municipalities. Hence we believe that the numbers presented in this paper are accurate.

The population in the municipality of Kärkölä has been stable, and observations for the update period (1987-2006) have mainly been based on the population that has been living in Kärkölä for decades. We did not find any essential variation in the SIR patterns within the update period. There were no significant interactions with age either. We know from the earlier study (6) that sawmill work or exposure to fungicides elsewhere was not associated with an increased risk of any cancer. Only one of the soft-tissue sarcomas was related to sawmill work.

Although minor changes may occur along with the very newest cancer registrations that come in, or as a consequence of continuous quality-control operations in the entire cancer registry database, this study repeated the findings of a significantly elevated risk for non-Hodgkin's lymphoma and soft-tissue cancer during population exposure to chlorophenols that were observed in the original study (6). No explanation could be found for the elevated colon cancer risk before the exposure. A novel finding was the unincreased incidence of these cancers in the period after the chlorophenol exposure was stopped.

Our current results offer further evidence of chlorophenols as a cause of malignant lymphoma and softtissue cancer. The action of chlorophenols is consistent with the promotion effect demonstrated in some animal studies $(13,14)$. The promoter role of the chlorophenols fits with the observation that the incidence of non-
Hodgkin's lymphoma and soft-tissue cancer returned to the expected level soon after the population exposure to chlorophenols via tap water was over.

There has been a long discussion on the carcinogenic potential of polychlorinated dioxins (PCDD or PCDF). In most epidemiologic studies, it has only been possible to study the effects of a mixed (occupational) exposure involving both dioxins and chlorophenols. Therefore, information on pure exposures to dioxins and pure exposures to chlorophenols is of importance in relation to the significance to the cancer risk of either group of chemicals or both of them. In a recent study, a chlorophenol-independent exposure to PCDD or PCDF was not associated with an increased risk of soft-tissue sarcoma in a normal nonoccupational population (7). Our study demonstrates that chlorophenols alone without PCDD or PCDF contamination may be associated with both softtissue cancer and non-Hodgkin's lymphoma.

The experience in Kärkölä is an example of a successful active cancer prevention carried out by local authorities, who stopped the operation of the old water intake plant and built a new plant. Our finding-if not by chance-would fit with the thinking that the stage of promotion is the most effective site to target for both active and passive cancer prevention (16).

\section{References}

1. Lampi P, Vartiainen T, Tuomisto J, Hesso A. Population exposure to chlorophenols, dibenzo-p-dioxins and dibenzofurans after prolonged ground water pollution by chlorophenols. Chemosphere. 1990;20(6);625-34.

2. Lampi P, Tolonen K, Vartiainen T, Tuomisto J. Chlorophenols in lake bottom sediments: a retrospective study of drinking water contamination. Chemosphere.1992;24(12):1805-24.

3. Vartiainen T, Lampi P, Tolonen K, Tuomisto J. Polychlorodibenzo-p-dioxin and polychlorodibenzofuran concentrations in lake sediments and fish after a ground water pollution with chlorophenols. Chemosphere. 1995;30(8):1439-51. 
4. Vartiainen T, Lampi P, Tuomisto JT, Tuomisto J. Polychlorodibenzo-p-dioxin and polychlorodibenzofuran concentrations in human fat samples in a village after pollution of drinking water with chlorophenols. Chemosphere. 1995;30(8):142938.

5. Lampi P, Vohlonen I, Tuomisto J, Heinonen OP. Increase of specific symptoms after long-term use of chlorophenol polluted drinking water in a community. Eur J Epidemiol. 16;(3):245-51

6. Lampi P, Hakulinen T, Luostarinen T, Pukkala E, Teppo L. Cancer incidence following chlorophenol exposure in a community in southern Finland. Arch Environ Health. 1992;47(3):167-75.

7. Tuomisto JT, Pekkanen J, Kiviranta H, Tukiainen E, Vartiainen T, Tuomisto J. Soft-tissue sarcoma and dioxin: a case-control study. Int J Cancer. 2004;108:893-900.

8. Hoppin JA, Tolbert PE, Herrick RF, Freedman DS, Ragsdale $\mathrm{BD}$, Horvat KR, et al. Occupational chlorophenol exposure and soft tissue sarcoma risk among men aged 30-60 years. Am J Epidemiol. 1998;148:693-703.

9. Garabedian MJ, Hoppin JA, Tolbert PE, Herrick RF, Brann EA. Occupational chlorophenol exposure and non-Hodgkin's lymphoma. J Occup Environ Med. 1999;41:267-72.

10. Demers PA, Davies HW, Friesen MC, Hertzman C, Ostry A, Hershler R, et al. Cancer and occupational exposure to pentachlorophenol and tetrachlorophenol (Canada). Cancer Causes
Control. 2006;17:749-58.

11. Van den Berg M, de Jongh J, Poiger H, Olson JR. The toxicokinetics and metabolism of polychlorinated dibenzo-p-dioxins (PCDD) and dibenzofurans (PCDF) and their relevance for toxicity. Crit Rev Toxicol. 1994;24:1-74.

12. Richardson DB, Terschüren C, Hoffmann W. Occupational risk factors for non-Hodgkin's lymphoma: a population-based case-control study in Northern Germany. Am J Ind Med. 2008;51:258-68.

13. Umemura T, Kai S, Hasegawa R, Sai K, Kurokawa Y, Williams GM. Pentachlorophenol (PCP) produces liver oxidative stress and promotes but does not initiate hepatocarcinogenesis in B6C3F1 mice. Carcinogenesis. 1999;20(6):1115-20.

14. Sai K, Kang KS, Hirose A, Hasegawa R, Trosko JE, Inoue T. Inhibition of apoptosis by pentachlorophenol in v-myc-transfected rat liver epithelial cells: relation to down-regulation of gap junctional intercellular communication. Cancer Lett. 2001;28;173(2):163-74.

15. Teppo L, Pukkala E, Lehtonen M. Data quality and quality control of a populationbased cancer registry: experience in Finland. Acta Oncol.1994;33(4):365-9.

16. Pitot HC. Multistage carcinogenesis-genetic and epigenetic mechanisms in relation to cancer prevention. Cancer Detect Prev. 1993;17(6):567-73.

Received for publication: 22 October 2007 